\title{
The Innovation and Creativity of Religious Moderation Learning Through Sociology Learning and Pancasila and Citizenship Education in Public Schools and Madrasas Gorontalo City
}

\author{
Israpil ${ }^{1)}$, Suardi ${ }^{2)}$ \\ Religion and Development Research Center Makassar, Indonesia ${ }^{1)}$ \\ Sociology Education Universitas Muhammadiyah Makassar, Indonesia ${ }^{2)}$ \\ israpilpenda@gmail.com ${ }^{1)}$, suardi@unismuh.ac.id $^{2)}$
}

\begin{abstract}
This study aims to explore educators' ideas regarding learning materials and methods that integrate moderation insights by utilizing creative learning media carried out in public schools and madrasas. The value of moderation insight is urgent to be implemented for students, given the widespread dissemination of information through misleading online media, including intolerant religious messages. This study used a qualitative descriptive approach, with data collection conducted through interviews and FGDs. The results of the study show: (1) Educators are very creative in using learning media technology, including: zoom meeting applications, WhatsApp, Telegram, and Elearning. Platforms provided by Google (Google Classroom, Google Forms, Google Meet), Kingmaster, Filmmora, Font Art, Camtasia, Quizizz, Microsoft 365, and create innovative learning modules. (2) Materials containing the value of religious moderation are found and integrated in various subjects, including Pancasila and Citizenship Education Lessons. The effectiveness of the use of learning media through the media has a significant impact on students' attitudes and experience improvement, as well as seriousness in participating in learning boldly.
\end{abstract}

Keywords: Learning Innovation, Religious Moderation, Creative Media, Civics

\begin{abstract}
Abstrak. Penelitian ini bertujuan untuk mendeskripsikan dan menggali gagasan pendidik terkait materi dan metode pembelajaran yang mengintegrasikan wawasan moderasi beragama dengan memanfaatkan media pembelajaran secara kreatif yang dilaksanakan di sekolah umum dan madrasah. Nilai wawasan moderasi beragama urgen untuk diimplementasikan kepada peserta didik, mengingat maraknya penyebaran informasi melalui media online yang menyesatkan, termasuk pesan-pesan keagamaan yang intoleran. Penelitian ini menggunakan pendekatan deskriptif kualitatif, dengan pengumpulan datanya dilakukan melalui wawancara dan FGD. Hasil penelitian menunjukkan: (1) Kalangan pendidik sangat kreatif menggunakan teknologi media pembelajaran, meliputi: aplikasi zoom meeting, WhatsApp, Telegram, dan E-learning. Platform yang disediakan oleh Google (Google Classroom, Google Forms, Google Meet), Kingmaster, Filmora, Font Art, Camtasia, Quizizz, Microsoft 365, dan membuat modul pembelajaran yang inovatif. (2) Materi yang mengandung nilai moderasi beragama ditemukan dan diintegrasikan dalam berbagai mata pelajaran antara lain mata pelajaran sosiologi dan Pelajaran Pendidikan Pancasila dan Kewarganegaraan. Efektivitas penggunaan media pembelajaran melalui media kreatif berdampak secara signifikan terhadap sikap peserta didik dan peningkatan kehadiran, serta keseriusan dalam mengikuti pembelajaran secara daring.
\end{abstract}

Kata Kunci: Inovasi Pembelajaran, Moderasi Beragama, Media Kreatif, Sosiologi, PKn 


\section{INTRODUCTION}

Since the Covid-19 pandemic hit the world, the Unitary State of the Republic of Indonesia was no exception, it had a serious impact on the world of education so that learning activities could not run normally. Meanwhile, students must continue to receive education and learning services. The world of education is "forced" to change the learning model strategy from face to face to distance learning online fully.

To support distance learning activities, the Directorate General of Islamic Education has made several efforts during this emergency, including; 1) build e-learning applications, provide electronic textbooks, 3) promote support for the manufacture of teaching materials by madrasah teachers in cooperation in the form of videos, animations, lesson modules, electronic books to fill elearning content, 4) Madrasah Ramadan Syiar Program collaboration with Electronic Media every Monday to Friday during the month of Ramadan, 5) Cooperation with the Russian Embassy on the use of the dragon learn.org platforms, namely learning fun mathematics for Madrasah Ibtidaiyah students for free during the Covid 19 pandemic and so on. These efforts are to optimize educational services in madrasas during an emergency.

Some of the obstacles faced in distance learning, among others, limited human resources, limited facilities in the form of laptops or cell phones owned by students, difficulties in accessing the internet and limited internet quota for students provided by their parents, and so on. In addition, the implementation of distance learning during the Covid-19 emergency period varies from one madrasa to another, according to the perception and readiness of each madrasa (Basid \& Saimroh, 2020)

The era of globalization or 4.0 era, which is an era that is synonymous with matters related to the internet. Only by utilizing the internet network, interaction is very easy and fast even though not face to face. The presence of the internet is the main basis for the development of innovations in the field of technology. Earlier computers were capable of automation. However, with internet collaboration, a technological innovation called the Internet of Things (IoT) has emerged and has an impact on other new innovations such as big data, Artificial Intelligence (AI) or what is popularly known as artificial intelligence and machine learning. These innovations can connect machines with humans and generate data. The purpose of this innovation is to increase productivity by making it easier for humans to make the right decisions. (Kamal, 2020).

One of the impacts of the globalization era is the ease of accessing science and technology (science and technology) information, whether accessed directly via the internet related to learning (Suardi \& Syarifuddin, 2018) or indirectly through 
application media provided by several electronic vendors. Either paid or trial. One of the information media used in interacting and being part of human life, which is very phenomenal, is the smartphone. With the development of increasingly advanced smartphones into offering sites or online friendship networks. Social media is one of them. The high use of social media as a means of public communication raises various problems. Information disclosure on social media is a trigger for the high tendency of people to make hate speech, interpersonal interactions become uncontrollable. The effects will affect a person in the short and long term (Ningrum et al., 2019)

According to Haili, the trend of intolerance and radicalism in Indonesia has increased from time to time through social media (Supriadi et al., 2020). Several surveys or research results show this. One of the survey results conducted by the Center for the Study of Islam and Society (PPIM) UIN Jakarta in 2017 has found $34.3 \%$ of respondents from among young people agree that jihad is a movement against non-Muslims. Then a survey from the Wahid Institute found that there was a tendency for attitudes towards tolerance in Indonesia to increase from $46 \%$ to 54\% (Supriadi et al., 2020).

The phenomenon of religious radicalism has entered schools in various regions, school residents need early detection of students who show visible symptoms, such as physical characteristics and way of thinking. so they need to be embraced not avoided. And invited to return to the path of Islam with peace and coolness (Munip, 2012)

Strengthening religious moderation is one of the factors that can provide resistance to information that can erode morals, morals, and behaviour in the nation and state. Religious moderation provides a balanced and fair understanding of religion in accordance with religious teachings and values by paying attention to social values, morals, morals, and character.

Avoiding justification groups and permissiveness (accepting taboo things). Religious moderation is an activity to conduct a review so as not to deviate from the rules or norms and religious values, there is a balance between worldly life and the hereafter, reducing violence and avoiding extremes.

Therefore, strengthening and socializing religious moderation is needed in the world of education, both in educational institutions and in the learning process. Learning innovation based on religious moderation is one of the efforts to avoid radical religious understanding that is unwittingly obtained by students. Research on this theme is interesting to do, because the innovation of religious moderation learning through creative media is one of the alternative learning systems that can be developed in educational institutions. 
Based on the previous explanation, the problem of this research: how is the description of innovation in material development and the development of religious moderation learning methods, as well as creative media used in public schools and madrasas in Gorontalo City?

\section{RESEARCH METHODS}

This research is a descriptive study using a qualitative approach. Descriptive research is research that seeks to provide a systematic and careful description of factual facts and characteristics of a particular population (Zuriah, 2005). Descriptive research can also be called exploratory research, namely to explore and clarify a phenomenon or social reality, by describing several variables related to the problem or unit being studied. Data collection techniques were carried out by interview and FGD. Interviews and FGDs were conducted to explore various information compiled from several questions obtained from madrasa principals, educators, and education practitioners. This study targeted individual educators in madrasas and public schools who were chosen purposively with the consideration that these key informants had knowledge and experience in carrying out learning, including being able to adjust actual issues in the context of this research. Data processing and analysis were carried out based on the form and nature of the data collected. Data analysis was carried out systematically, which included organizing data, categorizing data, and interpreting it was based on the meaning and forms of reporting and then presented descriptively.

\section{DISCUSSION}

\section{Innovation Value of Religious Moderation}

in Learning Materials of Sociology and Pancasila and Citizenship Education

In the presentation of subject matter in class, both subjects and subjects of Pancasila and sociological education, there is an interaction between educators and students, to improve student learning outcomes, student skills and affective students (Suardi, 2017). The relationship between innovation and students' understanding of the material to be discussed is mutually reinforcing. The purpose of material innovation, among others, is so that students do not experience difficulties in understanding the subject matter.

The subject matter delivered is in accordance with the curriculum set by the government. Before the teacher gives the material, the teacher makes a Lesson Plan (RPP). In learning process, there are three activities that become the benchmark for educators, namely preliminary activities, corelearning activities, and closing activities.

According to Sukirman and Kasmad in the lesson plan, there are three activities, namely preliminary activities, core-learning activities, and closing activities (Anggraeni \& Akbar, 2018). The preliminary activities 
carried out by fostering attention and motivation. In this activity, the teacher opens lessons according to their respective styles, creates a fun, democratic learning atmosphere, checks the attendance and readiness of students, conveys the goals/competencies to be achieved and then relates them to the subject matter, then explains the activities or learning experiences that will be carried out. must be done by students. Core learning activities, where teachers must be able to create fun, interactive, inspiring, and challenging learning conditions and foster student independence. According to Permendikbud No. 81 of 2014, in the core learning activities, there are at least 5 things that happen, namely: (1) students observe, (2) students ask questions, (3) students explore, collect various kinds of information from various sources including teachers, (5) students process information, and (5) students communicate or present, and reason based on observations. Then the last is the closing activity, the teacher gives a thorough explanation of what has been learned or summarizes, gives assignments, gives tests, reflects and draws conclusions.

The learning process is all educators apply the same pattern, although with different models and methods, the important thing is that it can make students learn (Suardi \& Nursalam, 2020)

The learning materials delivered at madrasas and public schools are still based on the K13 curriculum. However, educators continue to innovate and be creative so that the learning materials delivered can be fun and easy to understand, and can be practised or applied by students. Especially with materials that directly intersect or contain the value of religious moderation.

Understanding of religious moderation to students as future leaders, so as not to become an extreme generation, intolerant and exposed to radicalism. Thus, it is necessary to have a deeper understanding of religious moderation from an early age to the millennial generation so that they have a polite attitude, like harmony, mutual respect, and respect and accept differences.

The learning process is all educators apply the same pattern, although with models and different methods, the important thing is that it can make students learn (Suardi \& Nursalam, 2020)

The learning materials delivered at madrasas and public schools are still based on the K13 curriculum. However, educators continue to innovate and be creative so that the learning materials delivered can be fun and easy to understand, and can be practised or applied by students. Especially with materials that directly intersect or contain the value of religious moderation.

Understanding of religious moderation to students as future leaders, so as not to become an extreme generation, intolerant and exposed to radicalism. Thus, it is necessary to have a deeper understanding of religious 
moderation from an early age to the millennial generation so that they have a polite attitude, like harmony, mutual respect and accept differences.

The understanding of religious moderation at MTsN 1 Gorontalo, among other things, was instilled from the time they set foot in MTsN 1, when students took part in the 3-day takruf madrasa period. In this activity, students were introduced how to appreciate differences from various ethnic groups, as it is known that students at MTsN 1 Gorontalo City come from various backgrounds and quite diverse regional origins, some from Manado, Makassar, with different regional languages, how can respect one another.

In terms of curriculum, religious moderation learning materials have not been specifically accommodated in the curriculum. However, educators have innovated to insert the value of religious moderation in teaching and learning process. Strengthening religious moderation in students is still understood, such as before learning begins, starting with developing stories or information, for example about tolerance and anti-violence, fake news or hoaxes. The issue of hoax news, for example, invites them to read and fully see the circulating news, not to spread the news that can cause hostility that is not necessarily true. The value of religious moderation conveyed by the educators mentioned above is an apperception activity, with the aim of creating a sense of empathy for students and being motivated to do the right things.

\section{Educator Creativity Using Learning Media}

One of the goals of educators using creative and innovative learning media is that learning is more interesting and not boring. Learning media can arouse the curiosity of students; stimulate students to react to the teacher's explanation. Thus, learning is not monotonous and boring. Students are no longer passive participants but become active students.

It has been described previously, that the dominant educators in the research targets have been creative and innovative using learning media, both web-based through online and conventionally face-to-face in teaching and learning process which contains values of religious moderation. Web-based learning model is a learning model designed to integrate face-to-face conventional learning models with web-based learning models. (Rusman, 2011).

The research findings during the COVID-19 pandemic were that educators were dominantly using web-based learning media, using e learning. Besides that, some combine it with several learning media using the Google platform (Google Classroom, Google Forms, Google Meet), the zoom application, Microsoft PowerPoint, WhatsApp, Telegram. Like Google Classroom 
which is very effectively used in learning (Suardi \& Nursalam, 2020)

In addition, some educators make innovative learning modules.

Educators in madrasas and schools continue to innovate using creative learning media, both web-based and conventional faceto-face. To be even more interesting, there are several other complementary applications, including Kinimaster Application, Filmora, Font Art, Camtasia, Quizizz (for assessment), Microsoft 365, OBS (Open Broadcaster Software), and Youtube.

They learn these applications either selftaught or follow technical guidance facilitated by schools and related agencies. The learning media is used to catch up with learning during the COVID-19 pandemic. Applications used by educators are very helpful in the learning process, but each application has advantages and disadvantages. Therefore, that madrasas and public schools continue to evaluate the learning media used, including evaluating the entire learning process (Kanji et al., 2019).

During this pandemic, almost all schools and madrasas conduct virtual learning with the zoom application. However, this application has many drawbacks. Educators quite popularly use this application, but over time, students start to get bored and bored, so schools and madrasas are replacing the application with Microsoft 365 and other applications, as a form of innovation from educators, because they are required to be more creative in choosing more innovative learning media.

In online learning, there are many obstacles, including not all students have cell phones, have internet networks, and quotas, and some of them come from underprivileged families. To anticipate these obstacles, educators initiate by involving students in face-to-face learning on a limited basis. In addition, to make the virtual learning process more effective, there are several schools holding or opening learning studios. The formation of a learning studio is a form of innovation and creativity to overcome the obstacles faced during online or virtual learning. Like what was done by MTsN 1 Gorontalo City, SMAN 1, and SMAN 3 Gorontalo City.

At MTsN 1 Kota Gorontalo, an innovative learning studio was created, with the name MTsN Go Tv. This media is one of the solutions in educational services to overcome distance learning, by producing learning content and making the studio broadcasting information for madrasah activities both intra and extracurricular.

The objectives of the MTsN 1 Go Tv learning study are to bring madrasas closer to meeting the needs of the National Education Standards service in terms of providing facilities and infrastructure based on Information and Communication Technology (ICT); Organizing an increase in the competence of educators and education 
personnel in the management of information and communication technology-based activities; To support the Independent Learning program that has been launched by the Education Materials and is supported by the Ministry of Religion; Provide information to the public about the programs, activities, achievements of MTsN 1 Gorontalo City and the Ministry of Religion Program; Development of students' creativity; Provide opportunities for students to master the development of science and technology.

In addition, other benefits of this learning studio are: Availability of studio equipment for students and teaching staff in the context of improving the quality of education and fulfilling national education standard services; Creating an effective, efficient, fun and easy ICT-based learning process for students and teaching staff; It is easy for students to access learning videos; Showing up to date performance activities at MTsN 1 Gorontalo City and the Ministry of Religion Program; Optimizing the ability of students to channel creativity and innovation in extra-curricular activities; and optimizing information technology-based learning programs. Although it is still relatively new, when it was inaugurated in November 2021, currently MTsN 1 Go Tv, not only disseminates madrasa activities but also disseminates information within the Ministry of Religion in Gorontalo Province.
Two programs are broadcast at the MTsN 1 Go Tv studio, namely: academic programs and non-academic programs. Academic programs, in the form of learning video production programs made by educators and joint learning programs for educators display, live learning on YouTube and Facebook accounts. Non-academic programs are programs which are packaged creatively, such as a week's news. News a week presents information on activities at madrasas and other activities within the scope of the Ministry of Religion in Gorontalo City for a week. Then the madrasa chat program. This event usually presents information about the socialization of regulations or legislation within the Ministry of Religion, the Islamic pearl program, and on Friday, religious leaders are invited to give religious lectures. Brodkes program events or educational chats on student creativity, looking for talented talents from students to be displayed, students' creativity like playing the violin, and inspiring stories from successful figures.

However, the learning studio at MTsN 1 does not yet have a special TV channel like national television. The content or information submitted can only be watched via Youtube and Facebook of Madrasah Tsanawiyah Negeri 1 Gorontalo City. Even so, the innovations made by MTsN 1 Gorontalo City are a matter of pride, especially the Ministry of Religion of Gorontalo and become an 
inspiration for other madrasas in Gorontalo Province.

A similar innovation was also carried out by SMAN 1 Kota Gorontalo, which carried out the creativity in learning media in the form of a learning studio using the OBS (Open Broadcaster Software) application. The advantage of the application is that learning materials can be done audio-visually (live streaming) in real-time. It also makes it easier to make audio-visual recordings and make learning video materials. Educators and students interact directly like face-to-face learning.

In this learning studio, every educator is required to make a PowerPoint (PPT), and then it is given to the IT team to be developed. Educators in the learning process at SMAN 1 Gorontalo City use scheduled learning studies.

Likewise, most educators at Madrasah Ibtidaiyah Muhammadiyah Gorontalo City do, by making innovative learning modules to make them more interesting. The displays in the module are embedded with several colourful animated images, and can be connected to the applications that have been provided.

\section{CONCLUSION}

The subject matter delivered by educators is based on curriculum demands or based on available textbooks or pocketbooks. The subject matter and the theme of moderation are two things that do not intersect directly, but in the learning process, educators have innovated to insert or integrate religious moderation insights into the learning process. The subject matter which is in direct contact with the values of religious moderation, namely Civics, is related to the attitude of nationalism, love for the Unitary State of the Republic of Indonesia at the madrasah and public school levels. Educators are very creative in using learning media in teaching material that contains the value of religious moderation, among others, by using available platforms and applications. In addition, educators use learning video media, make power points (PPT), learning modules, and provide learning studio facilities in schools and madrasas. The innovation of religious moderation learning through creative media is presented so that students are interested and more serious. Religious moderation needs to be instilled through the attitudes of students, so that students are willing to accept differences, are tolerant, anti-violent, and know the local culture. The creative media used are the Zoom meeting application, WhatsApp, Telegram, and E-learning. Using the platform provided by Google (Google Classroom, Google Forms, Google Meet). Applications such as innovative Microsoft Powerpoint, Kingmaster, Filmmora, Font Art, Camtasia, Quizizz, Microsoft 365, innovative learning modules. The effectiveness of creative and innovative use of learning media has a significant impact on student attitudes and increased attendance, as 
well as the seriousness of students in participating in online learning. Massive socialization of religious moderation education is needed through training, workshops, seminars, and other technical guidance to provide an understanding of religious moderation to educators in schools and madrasas.

\section{REFERENCES}

[1] Anggraeni, P., \& Akbar, A. (2018). Kesesuaian Rencana Pelaksanaan Pembelajaran Dan Proses Pembelajaran. Jurnal Pesona Dasar, 6(2), 55-65. https://doi.org/10.24815/pear.v6i2.12197

[2] Abdullah, Ramli. 2016. "Pembelajaran Dalam Perspektif Kreativitas Guru Dalam Pemanfaatan Media Pembelajaran”. Jurnal. Lantanida Journal, Vol. 4 No. 1, 2016

[3] Agus, Maulana. DeVito. Joseph A. 2011. Komunikasi Antarmanusia Edisi Kelima. Alih Bahasa Maulana. Agus. (Tangerang Selatan : Karisma, 2011), 67

[4] Arsyad, Ahmad . 2003. Media Pembelajaran. Jakarta: Raja Grafindo Persada

[5] Atsani, Zainuddin Muhammad, Lalu Gede. 2020. "Transformasi Media Pembelajaran Pada Masa Pandemi Covid-19". Jurnal. AlHikmah Jurnal Studi Islam Volume 1 Nomor 1 Tahun Terbitan Januari-Maret. Lombok Timur: LP2M IAIH NW.

[6] Ananda, Rusydi dan Amiruddin. 2017. INOVASI PENDIDIKAN: Melejitkan Potensi Teknologi dan Inovasi Pendidikan. Medan: Widya Puspita.

[7] Basid, A., \& Saimroh. (2020). Kesiapan Pesantren Di Era Kenormalan Baru. In Pembelajaran Jarak Jauh Era Covid-19.

[8] Baharun, H., Bali, M. M. E. I., Muali, C., \& Munawaroh, L. 2020. "Self-Efficacy sebagai Media Peningkatan Profesionalisme Guru di Madrasah". Jurnal Risalah: Jurnal
Pendidikan Dan Studi Islam, 6(1), 244-257. Bali, M. M. E. I.

[9] Baruadi, Moh. Karim. 2012. "Sendi Adat dan Eksistensi Sastra: Pengaruh Islam Dalam Nuansa Budaya Lokal Gorontalo". Jurnal el Harakah Vol.14 No.2 Tahun 2012. Malang: UIN Malang

[10] Edi, Sutrisno. 2019. "Aktualisasi Moderasi Beragama di Lembaga Pendidikan". Jurnal Bimas Islam Vol. 12 No. 1.

[11] Faridi, Abdurrachman. 2009. "Inovasi Pembelajaran Bahasa Inggris Berbasis Ict Dalam Rangka Meningkatkan Mutu Pendidikan." Lembaran Ilmu Kependidikan 38 (1): 59-67.

[12] Junaedi, Edi. 2019. "Telaah Pustaka. Inilah Buku Moderasi Beragama Perspektif Kementerian Agama”. Jurnal. Multikultural \& Multireligius Harmoni. Vol. 18 No. 2. Jakarta: Badan Litbang dan Diklat Kementerian Agama RI.

[13] Kanji, H., Nursalam, N., Nawir, M., \& Suardi, S. (2019). Evaluasi Integrasi Pendidikan Karakter dalam Pembelajaran Ilmu Pengetahuan Sosial di Sekolah Dasar. JED (Jurnal Etika Demokrasi), 4(2), 56-63. https://doi.org/10.26618/jed.v4i2.2386

[14] Kamal, Irsyad, dkk. Pembelajaran di Era 4.0 Aplikasi Teknologi Informasi dan Pembelajaran. Bandung: Yrama Wedia.

[15] Kementerian Agama RI. 2019. Peraturan Dirjen Pendidikan Islam Nomor 2791 Tahun 2019 Tentang Kurikulum Darurat. Jakarta: Pendis Kemenag RI.

[16] Munip, A. (2012). Menangkal Radikalisme di Sekolah. Jurnal Pendidikan Islam, I(1), 159182.

[17] Maili, Mashadi \& Wahidah Suryani. 2018. "Jaringan Islamisasi Gorontalo (Fenomena Keagamaan dan Perkembangan Islam di Gorontalo" Jurnal Al-Ulum. Volume 18 Number 2 December 2018. p.435-458 https://doi.org/10.30603/au.v18i2.555. Madura: Universitas Islam.

[18] Muflihin, Muh. Hizbul. 2009. "Aplikasi Dan Implikasi Teori Behaviorisme Dalam 
Pembelajaran (Analisis Strategis Inovasi Pembelajaran).”Khazanah Pendidikan, 1-11.

[19] Ningrum, D. J., Suryadi, S., \& Chandra Wardhana, D. E. (2019). Kajian Ujaran Kebencian Di Media Sosial. Jurnal Ilmiah KORPUS, 2(3), 241-252. https://doi.org/10.33369/jik.v2i3.6779

[20] Nurdin, Arbain. 2016. "Inovasi Pembelajaran Pendidikan Agama Islam Di Era Information and Communication Technology." Jurnal Tadris: Jurnal Pendidikan Islam 11 (1): 49. https://doi.org/10.19105/tjpi.v11i1.971.

[21] Nurryana, Ayu Fiska. 2009. "Pengembangan Media Pendidikan Untuk Inovasi Pembelajaran Di Pesantren." Speed: Sentra Penelitian Engineering Dan Edukasi 1 (2): 15. https://doi.org/10.35891/amb.v5i2.2153.

[22] Rusman. 2011. Model-Model Pembelajaran: Mengembangkan Profesionalisme Guru. Jakarta: Rajawali Pers.

[23] Suardi. (2017). Peningkatan Hasil Belajar Sosiologi Pokok Bahasan Interaksi Sosial Melalui Metode Diskusi pada Siswa Kelas X MA. Muhammadiyah Panaikang Kacamatan Bissappu Kabupten Bantaeng. Jurnal Etika Demokrasi Pendidikan Pancasila Dan Kewarganegaraan, II(1), 2339-2401. https://doi.org/10.26618/JED.V2I1.1145

[24] Suardi, \& Nursalam. (2020). Penerapan Model Pembelajaran Saintifik Approach Berbasis Media Classroom | Indonesian Journal of Sociology, Education, and Development. Indonesian Journal of Sociology, Education, and Devolopment, 2(2), 88-97. http://ijsed.ap3si.org/index.php/journal/articl e/view/vol2iss2_2020_2suardi

[25] Suardi, \& Syarifuddin. (2018). Penerapan Model Pembelajaran Saintifik Approacd Berbasis Media Pembelajaran Kearifan Lokal pada Mata Kuliah Dasar-Dasar Sosiologi dalam Membangun Karakter dan Meningkatkan Hasil Belajar Mahasiswa Pendidikan Sosiologi Universitas Muhammadiyah Makassar. JED (Jurnal Etika Demokrasi), 3(2), 75-85. https://doi.org/10.26618/jed.v3i2.1627
[26] Shalikhah, Norma Dewi, Ardhin Primadewi, and Muis Sad Iman. 2017. "Media Pembelajaran Interaktif Lectora Inspire Sebagai Inovasi Pembelajaran.” Warta LPM $20 \quad$ (1): 9-16. https://doi.org/10.23917/warta.v19i3.2842.

[27] Sugianto, Hendi. 2020. Inovasi Pembelajaran PAI Pada Mata Pelajaran Fiqh. Jurnal. Pedagogik vol. 7 No. 02 Juli-Des 2020. Probolinggo: Universitas Nurul Jadid (UNUJA).

[28] Supriadi, E., Ajib, G., \& Sugiarso, S. (2020). Intoleransi dan Radikalisme Agama: Konstruk LSM tentang Program Deradikalisasi. JSW (Jurnal Sosiologi Walisongo), 4(1), 53-72.

[29] Sutrisno, Edy. "Aktualisasi Moderasi Beragama di Lembaga Pendidikan”. Jurnal Bimas Islam Vol 12 No. 1. Jakarta: Direktorat Jenderal Bimbingan Masyarakat Islam.

[30] Tim Penyusun Kementerian Agama. 2019. Tanya Jawab Moderasi Beragama. Jakarta: Badan Litbang dan Diklat Kementerian Agama RI.

[31] Zuriah, Nurul. 2006. Metodologi Penelitian Sosial Dan Pendidikan Antara Teori Dan Praktek. Jakarta: PT. Umi Aksara. 